石油技術協会誌 第 77 巻 第 5 号 （平成 24 年 9 月） $336 \sim 341$ 頁

Journal of the Japanese Association for Petroleum Technology

Vol. 77, No. 5 (Sept., 2012) pp. 336 341

\begin{tabular}{l}
\hline 講 演 \\
Lecture \\
\hline
\end{tabular}

\title{
Leveraging Unconventional Gas Technology and Expertise*
}

\author{
Mike Navarette $^{* *}$, Ken Williams ${ }^{* *}$ and Ron Dusterhoft ${ }^{* *}$
}

(Received August 10, 2012 ; accepted October 3, 2012)

\begin{abstract}
A holistic approach has been developed to assist in determining the remaining gas in-place in a source rock reservoir (SRR) that can be produced by drilling horizontal wells and hydraulically fracturing. SRR analysis helps identify locations in a basin where source rocks have sufficient total organic carbon (TOC) and maturity to have production potential. The conditions under which the rock was deposited determines the TOC and the richness of a SRR. The maturity depends on the geologic burial and temperature history of the rock since deposition.

To identify the boundaries of a play area that meets these conditions, 1D modeling and mapping of analysis can be used. In addition to production potential, the SRR needs to have sufficient thickness and brittleness to be able to hold a hydraulic fracture and remain open after the fracturing job has been completed. Rocks in the subsurface cannot be too complexly folded and faulted. This complexity prevents the construction of a long horizontal well.
\end{abstract}

Keywords ; Unconventional shale, Source rock reservoir, Natural fractures, micro-fractures, free porosity and kerogen filled volumes, Food industry grade fracturing fluid, Ultraviolet light bacteria control process, Electrocoagulation, Advanced dry polymer blender, Microseismic fracture mapping

\section{Introduction}

Recent developments are enabling operators to produce hydrocarbons from unconventional reservoirs both more efficiently and with an improved environmental profile. There appear to be four main parameters that are necessary for the production of gas from a SRR (Fig. 1). The organic richness of the rock, (TOC and richness) must be present. The rock must also have been buried deep enough to have generated oil and gas. Examples of rich source rocks without sufficient burial are the oil shales of the western US that are not currently commercial. SRRs need to have enough stimulation potential to be able to be hydraulically fractured and to hold that fracture without closing up and embedding the proppant. Lithology maps are made to evaluate this parameter. The fourth factor of critical importance is the complexity of the SRR. It must be possible to drill long horizontal wells within the SRR. Therefore, the SRR cannot be complexly folded and faulted. Structure maps are used to evaluate this parameter. When maps are made on these four key factors and overlain, the area of overlap identifies a play outline within which every well that is hydraulically fractured will produce oil and/or gas at some rate.

\footnotetext{
* 平成 24 年 6 月 6 日, 平成 24 年度石油技術協会春季講演会作井部門シン ポジウム「天然ガスビジネスにおける作井技術」で講演 This paper was presented at the 2012 JAPT Drilling Symposium entitled "Drilling Technologies for Natural Gas Development” held in Akita, Japan, June 6, 2012. **ハリバートン エナジー サービシィス Halliburton
}

Within the play outline, prospects are defined by mapping five additional parameters. The unit must have sufficient thickness to have enough gas in place to be attractive. The depth of the target needs to shallow enough to be able to drill a long horizontal well at a cost low enough to make the economics work.

Hydraulic fractures in the SRR need to be contained mostly within the unit and not extend into adjacent wet units that would shut off the production. Hydraulic fracturing of a SRRs creates a reservoir or a Stimulated Reservoir Volume (SRV) that interconnects natural fractures, micro-fractures, free porosity and kerogen filled volumes. Finally, the pressures

\section{Hydrocarbon Reservoir Type Classification}

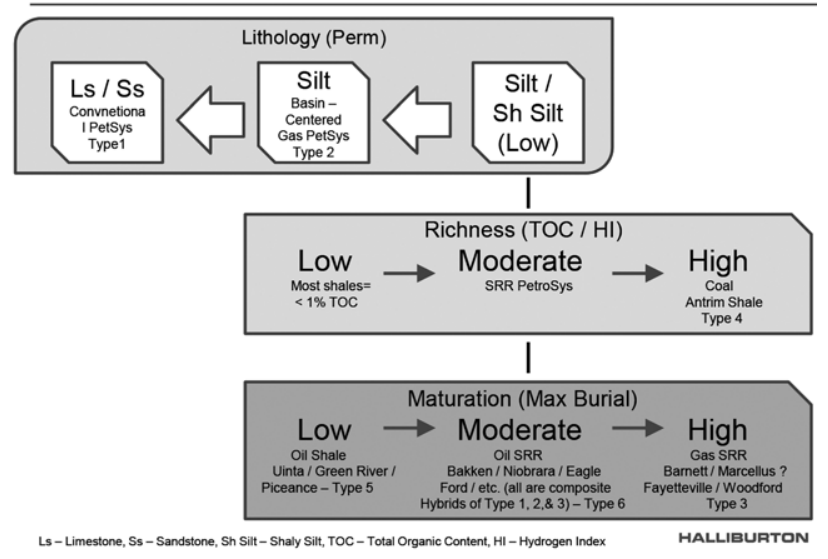

Fig. 1 Perspective on Gas Reservoir 
and stresses in the SRR need to be compatible with economic production and hydraulic fracturing. Geomechanical analysis of the well and seismic data can give information about these parameters. As with the play analysis, the overlay of the best areas of each of these maps will indicate where the best locations for acreage acquisition and drilling will be found. Several other parameters can be mapped and used to identify sweet spots within the prospects.

Many different parameters have been proposed for the evaluation of source rock reservoirs. There are geologic,

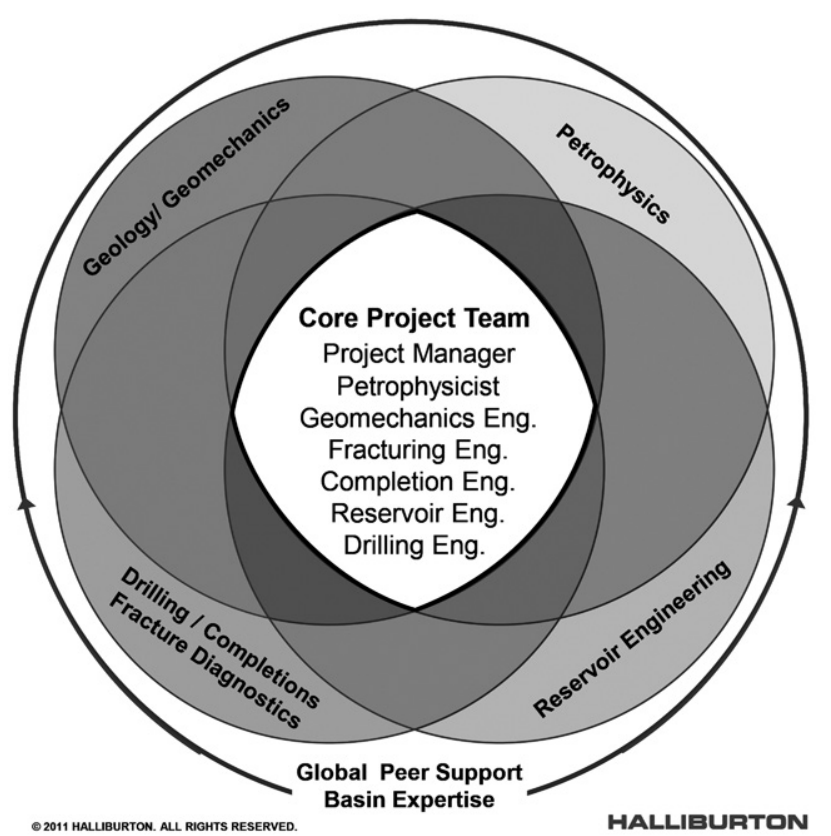

Fig. 2 Organizational collaboration geochemical, geomechanical, petrophysical, design, implementation and optimization considerations. Each of these have multiple parameters that can be examined. Depending on the project evaluated and the amount of information that is available, each of these subjects may need to be investigated. A complete evaluation of a project area may consist of four stages: geologic assessment, petrophysical evaluation, formation evaluation and reservoir modeling.

The geology of SRR units changes over large areas. Sufficient test wells need to be drilled and fully logged and/or tested to define this variability both vertically and horizontally. The completion conditions in one area of the field will not be appropriate for other areas. There is a significant "lost opportunity cost" involved in taking the risk that the geology does not change and that the same factory approach that works in one area of the field will work well in other areas.

Organizational collaboration is a key element to developing unconventional resources. All of the disciplines are interactive when performing the assessment, operational program, and optimization (Fig. 2).

A holistic approach should be considered for the development of the SRR asset. This approach starts with the concept that commercial SRR assets can be found in existing oil and gas producing basins. A high level screening of a potential SRR is made using existing well logs, drilling reports and cutting with initial unconventional analogs identified. Pilot wells either drilled or existing wells recompleted should not only be used to determine potential commerciality but to fill the gaps of missing data. In developing the SRR asset, it begins with the end in mind, fracturing designs, completions type, well types or architecture and drilling muds from analog fields should be tested and modified as determined

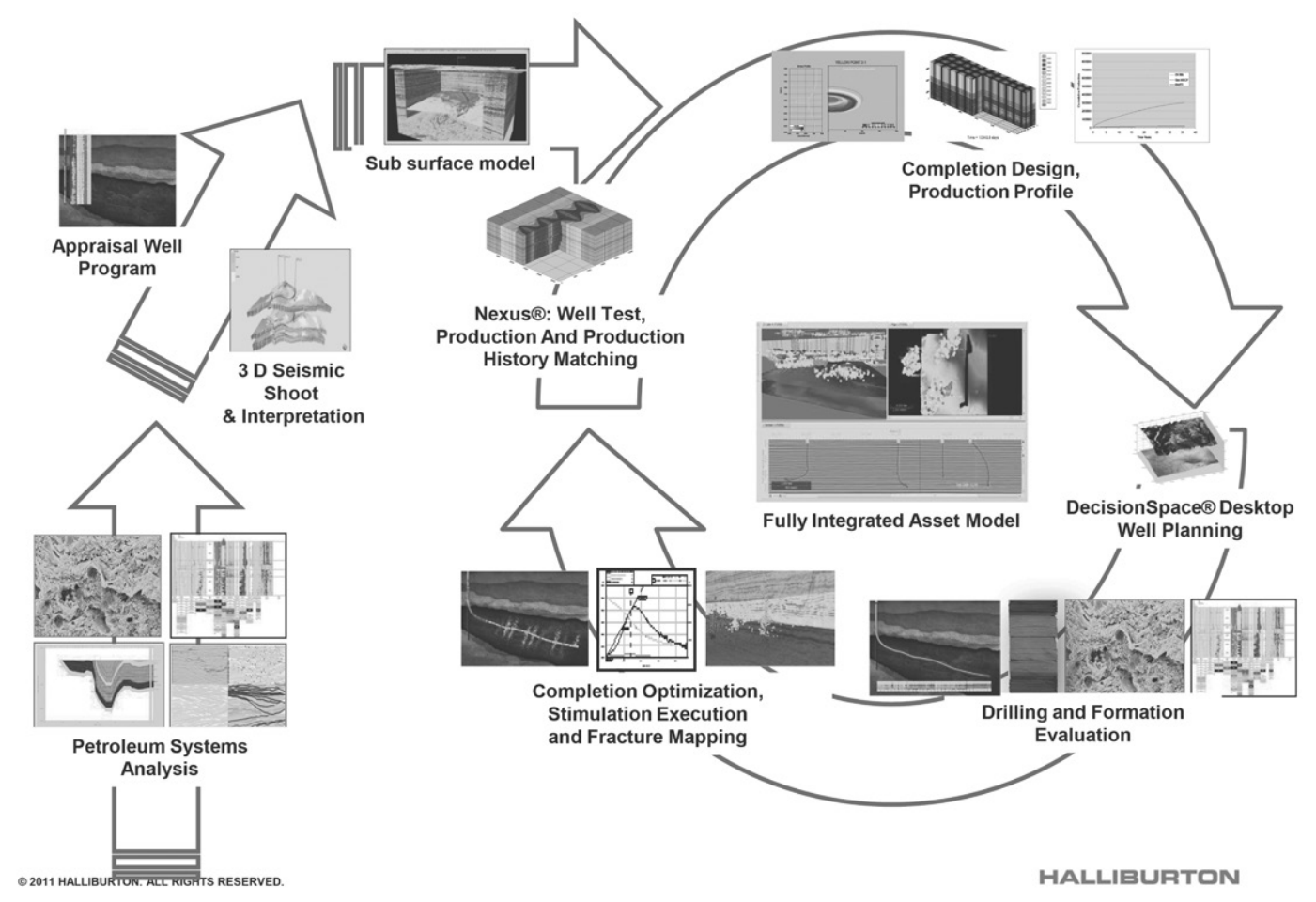

Fig. 3 Unconventional Field Development Workflow 
appropriate. Analogs fields are just the start, as more data is obtained from the SRR asset being developed; well, completion and fracturing designs need to be customized to the asset. Once these designs are customized, the process is repetitive: starting with the fracturing design and completion, then on to well planning, followed by drilling and data acquisition, ending with completions, fracturing, monitoring and production analysis and history matching.

A fully integrated asset model can be constructed from image $\log$ analysis in wellbores, microseismic analysis conducted during hydraulic fracturing, and regional geologic knowledge. This model can be used with other geological information about the field area to determine the most efficient way to develop the asset. The object is to get the most reserves out of the ground at a reasonable cost with the least environmental disruption (Fig. 3).

Advances in stimulation technologies developed that respond to environmental concerns are at the forefront of research and development efforts. Unconventional reservoirs developments require large amounts of fresh water. Several new areas currently under consideration for shale development are in environmentally sensitive locations, making water sourcing for fracturing operations even more critical. Fresh water use needs to be minimized and fracturing fluids essential for successful stimulation treatment should be comprised of chemical adhering to environmentally acceptable standards.

Latest developments in fracturing include an electrocoagulationbased water treatment service, a process that uses ultraviolet light to control bacteria, a fracturing fluid system comprising materials sourced entirely from the food industry and a system that blends fracturing fluids using dry powder.

\section{A New Hydraulic Fracturing Fluid System}

A hydraulic-fracturing fluid consisting of chemical components sourced solely from the food industry and approved by the Federal Drug Administration (FDA) as food additives safe for human consumption has been developed. The components include a gelling agent to provide fluid viscosity, a crosslinker to complex the gelling agent for proppant suspension and transport, a surfactant to prevent the generation of emulsions and water blocks with formation fluids, and a suite of breakers designed specific to temperature ranges to control the reduction of gelled viscosity over specific pumping times. CleanStim ${ }^{\circledR}$ is a new hydraulic fracturing fluid system that provides exceptional fracturing and environmental performance as compared to traditional formulations and is made with ingredients sourced from the food industry. Before use, the CleanStim formulation is mixed on-the-fly at the job site with the water provided by the operator.

CleanStim service is a major step change, what you might call a game changer in fracturing fluid technology. In addition to environmental benefits, the CleanStim fluid system provides excellent job performance in terms of pumpability, proppant transport and retained conductivity. Laboratory tests showed over $90 \%$ retained conductivity after $24 \mathrm{hr}$ of flow. The system is applicable over a broad temperature range providing up to 30 minutes pumping time at $225^{\circ} \mathrm{F}\left(107^{\circ} \mathrm{C}\right)$.

The CleanStim fluid system can be crosslinked and used either for conventional gelled fracturing treatments or the components can be used to provide friction reduction for water frac treatments commonly used in shale reservoirs

While high environmental standards were achieved with the development of Cleanstim hydraulic-fracturing fluid, fluid performance was not comprised. Moreover, in terms of proppant suspension, transport and proppant conductivity cleanup, Cleanstim fluid performance was superior to conventional fluid systems currently used in the industry ${ }^{1)}$.

\subsection{Field Results}

The CleanStim formulation is currently undergoing field trials with the system successfully used in a Midcontinent well, a Permian Basin well, and a Southeast Texas well over a temperature range of 120 to $225^{\circ} \mathrm{F}$. In all three cases, it provided excellent proppant transport, a clean break and better-than-expected fluid recovery. Initial production from all three wells was equivalent to (one well) or better than (two wells) expected.

\section{An Innovative Ultraviolet Light Bacteria Control System}

CleanStream ${ }^{\circledR}$ service, an ultraviolet (UV) light bacteria control process, uses a mobile unit capable of treating fracturing fluid at rates up to $100 \mathrm{bbl} / \mathrm{min}$ (Fig. 4). Operators who have used this service have significantly reduced the volume of biocides used to treat for aerobic and anaerobic (sulfate reducing) bacteria.

Unlike chemical approaches to water disinfection, UV irradiation provides rapid, effective inactivation of microorganisms through a physical process. When bacteria are exposed to the germicidal wavelengths of UV light, they are rendered incapable of reproducing or replicating. The CleanStream unit does not add much additional footprint on location and is placed between the frac tanks and blender (Fig. 5).

Using UV light for drinking water disinfection dates back to 1916 in the U.S. Over the years, UV costs have declined as researchers develop and use new UV methods to disinfect water and wastewater. Today UV light, for disinfection and bacteria control is extensively used and commonplace in hospitals, food processing and water treatment industries.

In water systems, bacteria exist as members of an aggregate called a biofilm. A biofilm is an aggregate of microorganisms in which cells adhere to each other on a surface. These adherent cells are frequently embedded within a self-produced matrix of extracellular polymeric substance (EPS). Biofilms, for the most part, may be invisible to the naked eye, such as in a flowing stream. In extreme cases, the biofilm may be a highly visible, bulky, slimy mass.

For the oilfield, problems associated with biofilms and bacterial growth are bio-fouling and plugging, corrosion of tanks and piping, and destruction of chemicals used to 
enhance production of oil and gas. Some of the more serious and longer term problems associated with bacteria come in the form of sulfate reducing bacteria (SRB) which reduce the sulfate ion to sulfide. In the presence of iron or steel, this can lead to the corrosion of iron or steel and adversely affect productivity

Controlling bacteria growth in fracturing fluid is critical since excess growth will lead to the corrosion of iron or steel or sour (H2S) fluids generation.

For example, a 10 million gallon water frac treatment that normally requires 10,000 gal of biocide can now be replaced using one CleanStream service unit and 1000 gal of biocide for conditioning. Recent enhancements to the system

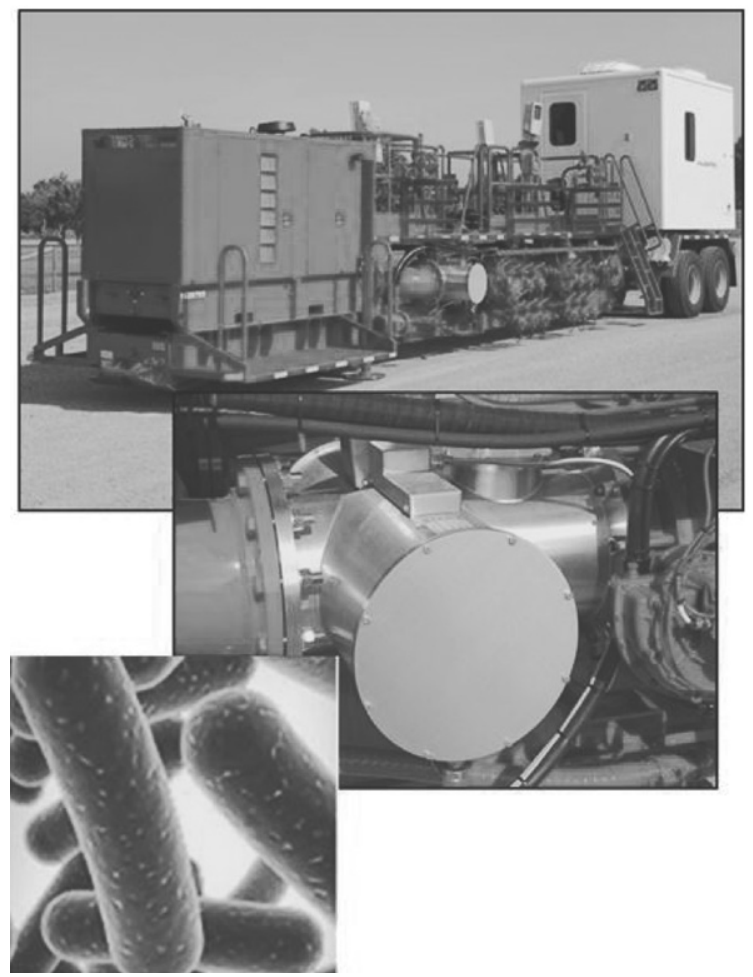

Fig. 4 CleanStream ${ }^{\circledR}$ service---Innovative Ultraviolet Light Bacteria Control system

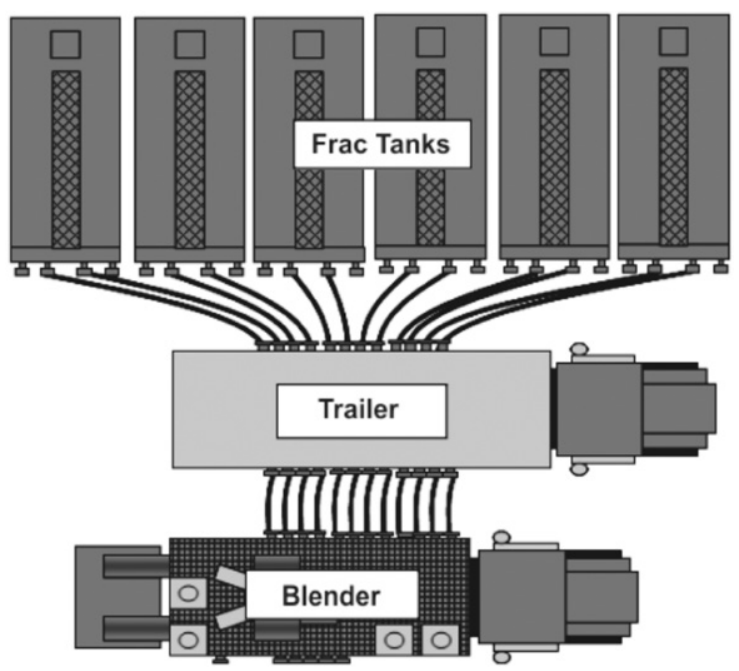

Fig. 5 CleanStream ${ }^{\circledR}$ wellsite layout wellsite logistics permitting now means that the utilization of CleanStream service on-the-fly, can reduce biocide addition to zero.

\section{Electrocoagulation enables recycling of flow back and produced water}

Electrocoagulation (Electro meaning to apply an electrical charge to water and Coagulation meaning the process of changing the particle surface charge, allowing suspended matter to form an agglomeration) is an advanced and economical water treatment technology. It effectively removes suspended solids to sub-micron levels, breaks emulsions such as oil and grease and / or latex from water without the use of filters or the addition of separation chemicals

Electrocogaulation or CleanWave ${ }^{\mathrm{SM}}$ service enables recycling of flow back and produced water at the wellsite. For every barrel of oil produced, approximately three barrels of water are produced. In addition, between $10 \%$ to $40 \%$ of the fluid volume used in fracturing operations, flows back during the subsequent clean-up (Fig. 6) .

This service is provided via a mobile electrocoagulation component that uses electricity to treat flowback and produced water at rates of up to $26,000 \mathrm{bbl} /$ day while using minimal power.

The CleanWave system destabilizes and coagulates the suspended colloidal matter in water. When contaminated water passes through the electrocoagulation cells, the anodic process releases positively charged ions, which bind onto the negatively charged colloidal particles in water resulting in coagulation. At the same time: gas bubbles, produced at the cathode, attach to the coagulated matter causing it to float to the surface where it is removed by a surface skimmer. Heavier coagulants sink to the bottom, leaving clear water, suitable for use in drilling and production operations.

Benefits associated with the use of the Clean Wave system include reduced transportation, procurement, and disposal costs for the operator in addition to the environmental considerations. Halliburton's CleanWave treatment enables operators to generate water for reuse in fracturing fluids or reuse in other drilling and production processes. This minimizes fresh water consumption and the costs associated

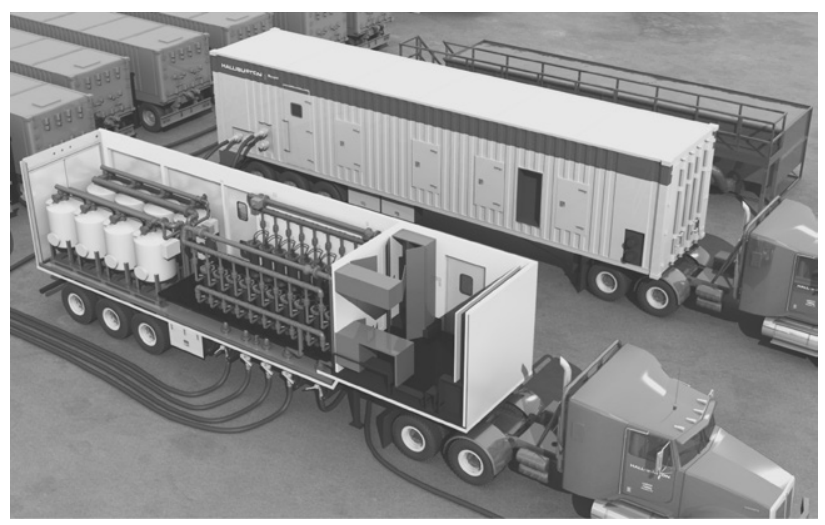

Fig. 6 CleanWave ${ }^{\mathrm{SM}}$ service---recycling of flow back and produced water at the wellsite 
with procurement and disposal.

\section{ADP $^{\mathrm{TM}}$ Advanced Dry Polymer Blender}

The ADP ${ }^{\mathrm{TM}}$ advanced dry polymer blender enables mixing any of Halliburton's fracturing fluids using a dry polymer, eliminating the need for hydrocarbon-based concentrates (Fig. 7).

The ADP advanced dry polymer blender is one outcome of Halliburton's continuing commitment to develop more environmentally focused fracturing fluid systems. The ADP blender employs mechanical-shearing techniques that provide sufficient polymer hydration without the use of a Liquid Gel Concentrator. This new blender enables any of Halliburton's fracturing fluid systems to be mixed from a dry powder.

ADP blenders achieve rapid hydration by adding gelling agents to water under appropriate shearing methods. By removing the inactive-ingredients from the carrier fluids in LGCs, chemical volumes were significantly reduced and environmental concerns using BTEX eliminated.

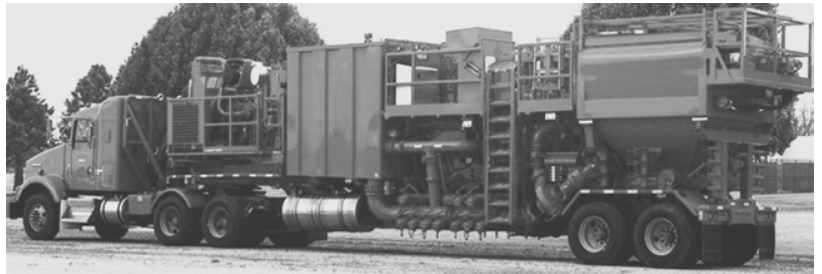

Fig. $7 \mathrm{ADP}^{\mathrm{TM}}$ advanced dry polymer blenderEliminating the need for hydrocarbon-based concentrates for fracturing fluids

\section{Microseismic Monitoring}

Microseismic fracture mapping provides an image of the fractures by detecting microseisms that are triggered by shear slippage on bedding planes or natural fractures adjacent to the hydraulic fracture. The location of the microseismic events is obtained using a downhole receiver array that is positioned at the depth of the fracture in an offset wellbore.

Microseismic fracture mapping is employed to improve

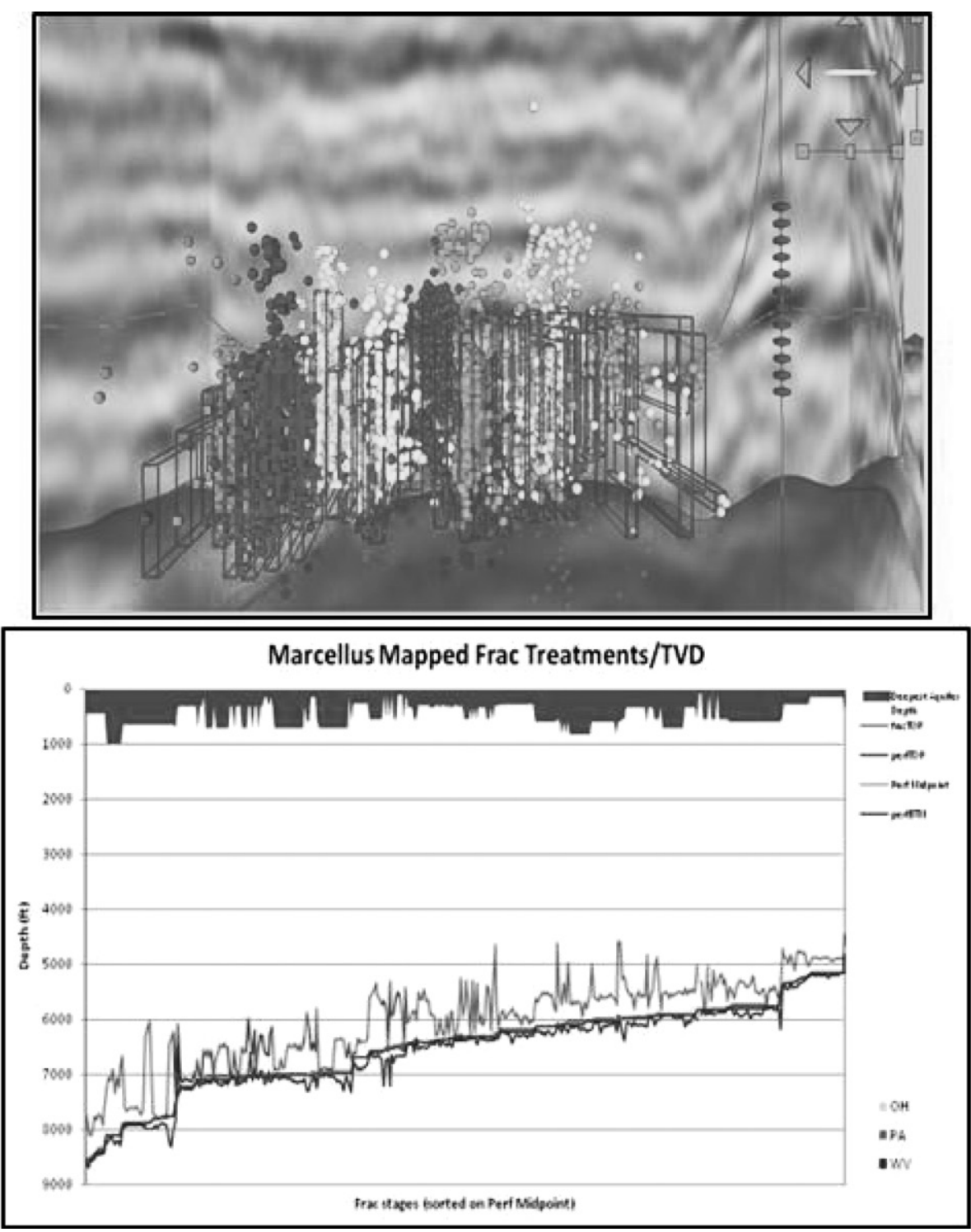

Fig. 8 Microseismic fracture mapping 
production economics by increasing reservoir productivity and/or reducing completion costs. This capability helps assure the fracture stays in the intended zone and that the complete zone is stimulated. This capability can help optimize production and minimize the number of wells and fractures required. Results from microseismic fracture mapping can be used to "calibrate" fracture growth models. Halliburton's fracturing and acidizing capabilities are aligned with Pinnacle's technologies and expertise to help provide operators a comprehensive solution to the complex exploration and production challenges of unconventional assets.

\subsection{Data Confirm Safety of Well Fracturing}

Extensive mapping of hydraulic fracture geometry has been performed in North American shale reservoirs since 2001. The data confirm the safety of fracturing as related to aquifers. In every case, a large distance in the thousands of feet exists (Fig. $8^{2)}$ ).

\section{Conclusions}

Each shale source rock is unique so basin modeling, geophysics, geochemistry and petrophysics understanding are required to define a unique set of attributes. TOC, thermal maturity, mechanical properties, reservoir fluid porosity, local and basin stress conditions along with other reservoir attributes need to be determined to Maximize Stimulation potential.

Clean technologies not only create value to the customers, are also bound to have an effect on public understanding and acceptance of hydraulic fracturing. Clean technologies are innovations that address the environmental, social and political needs of our industry. These technologies dramatically reduced the environmental footprint of the fracturing operation in Unconventional wells

\section{References}

1) David Loveless, et. al., 2011 : "Fracturing Fluids Comprised of Components Solely Sourced From the Food Industry Provide Superior Proppant Transport”, SPE, SPE 147206, $2-7$

2) Kevin Fisher, et. al., 2011 : "Hydraulic Fracture Height Growth: Real Data”, SPE, SPE 145949, 2-4

要旨

$$
\begin{gathered}
\text { 非在来型ガスの技術と専門知識の活用 } \\
\text { マイク ナバレット・ケン ウィリアムス } \\
\text { ロン ダステルホフト }
\end{gathered}
$$

近年の開発は, オペレーターに非在来型の貯留層から効 率的かつ改善された環境プロフィルで炭化水素の生産を可 能にしている。総体的なアプローチは, 水平坑井を掘削 し, 水圧破砕を行うことによって, 根源岩貯留層の中に存 在しているガスを開発してきた。根源岩貯留層の分析は, 根源岩が生産可能性を持つために十分な有機炭素と成熟度 を持っている場所を特定するのに役立つ。岩石が堆積した ときの条件は, 有機炭素と根源岩貯留層の豊かさを決定す る。成熟度は, 堆積以来の地質状態と温度履歴に依存する。

これらの条件に会うプレイエリアを識別するために, 1D モデリングと解析のマッピングを使用することができ る。生産可能性に加えて, 根源岩貯留層は水圧破砕を保持 し, フラクチャリング作業が終了まで開いたままに保てる のに十分な厚さと脆さを必要とする。地下で岩石が複雑に 褶曲していたり, 断層があってはならない。この複雑さは, 長い水平坑井の掘削に障害を起こす。 